\title{
KAJIAN HUKUM ONLINE DISPUTE RESOLUTION (ODR) DI INDONESIA BERDASARKAN UNDANG-UNDANG NOMOR 30 TAHUN 1999
}

\author{
Hutrin Kamil, M.Ali Mansyur \\ Dosen Fakultas Hukum UNISSULA \\ M_alimansur@yahoo.co.id
}

\begin{abstract}
Alternative dispute resolution (ADR) is an out of court dispute resolution. that the parties to the dispute by mutual agreement freely choose the form and procedures contained in the alternative dispute resolution and will be applied in the dispute resolution. One of the breakthrough by using a model of online arbitration, which is known as Online Dispute Resolution (ODR), so that the disputing parties can resolve anywhere he is. This research uses normative juridical approach, an approach to positive law or regulations reserved. By analyzing and evaluating legislation. Online dispute resolution process consists of: The parties agreed in the form of an agreement to resolve the dispute through arbitration online. Although legally, Online Dispute Resolution is not expressly provided in the Act No. 30 of 1999, does not mean there can be applicable in Indonesia. But the arbitrators and judges can use the method of the invention to overcome this law
\end{abstract}

Keywords: Arbitration, Alternative Dispute Resolution and ODR

\begin{abstract}
Abstrak
Alternatif penyelesaian sengketa (APS) merupakan penyelesaian sengketa di luar pengadilan. bahwa para pihak yang bersengketa bebas melalui kesepakatan bersama memilih bentuk dan tata cara yang terdapat dalam alternatif penyelesaian sengketa dan akan diterapkan dalam penyelesaian sengketanya. Salah satu terobosannya dengan menggunakan model arbitrase online, yang dikenal dengan istilah Online Dispute Resolution (ODR), sehingga para pihak yang bersengketa dapat menyelesaikan dimana saja dia berada. Penelitian ini menggunakan pendekatan Yuridis Normatif, merupakan pendekatan terhadap hukum positif atau peraturan perundang-undang. Dengan menganalisis dan mengevaluasi peraturan perundang-undangan. Proses penyelesaian sengketa secara online terdiri dari: Para pihak setuju dalam bentuk perjanjian untuk menyelesaikan sengketa melalui arbitrase online.Meskipun secara yuridis, Online Dispute Resolution tidak diatur secara jelas dalam UU No. 30 Tahun 1999, bukan berarti tidak dapat berlaku di Indonesia. Tetapi para arbiter dan hakim bisa menggunakan metode penemuan hukum untuk mengatasi hal tersebut.
\end{abstract}

Kata kunci : Arbitrase, Alternatif Penyelesaian Sengketa dan ODR

\section{A. PENDAHULUAN}

Era globalisasi sebagai akibat pesatnya kemajuan dibidang ekonomi transportasi dan komunikasi ternyata menimbulkan semakin besarnya saling ketergantungan antar bangsa, kemudian juga timbulnya tingkat kompensasi yang semakin tajam. Persaingan yang semakin keras membawa tuntutan pada kualitas produk dan tingkat efesiensi yang semakin tinggi'

Dalam model bisnis yang melewati yurisdiksi negara biasanya alternatif penyelesaian sengketa yang diambil adalah metode arbitrase yang menjembatani kepentingan hukum dengan

1 M. Ali Mansyur, 2012, Peran Hukum Dalam Menjawab Perkembangan Ekonomi, Badan Penerbit Universitas Diponegoro, Semarang, hlm. 40. 
sistem hukum yang berbeda. Pemasalahannya metode arbitrase yang ada ternyata masih menggunakan model konvensional yang mengharuskan pihak-pihak yang bersengketa untuk bertemu secara langsung, padahal dalam e-bussines pihak-pihak yang melakukan hubungan hukum berasal dari berbagai belahan dunia. Oleh karena itu dunia bisnis modern berpaling kepada Alternatif Dispute Resolution (ADR) atau Alternatif penyelesaian sengketa (APS), sebagai penyelesaian sengketa alternatif karena keperluan bisnis modern menghendaki penyelesaian sengketa yang cepat dan tidak menghambat iklim bisnis. Alternatif penyelesaian sengketa (APS) merupakan penyelesaian sengketa di luar pengadilan. Dengan memilih metode Alterbatif Penyelesaian Sengketa (APS) pihak yang bersengketa seharusnya mengacu kepada kontraknya sendiri (jika ada) yaitu pada klausul kontrak yang menunjukkan kepada pihak ketiga untuk membantu jika negosiasi tidak berhasil, yaitu jasa-jasa baik, mediasi, dan konsiliasi di satu pihak serta arbitrase di tempat lain².

Disinilah diperlukan sebuah metode arbitrase yang dapat menjembatani berbagai kepentingan hukum dengan sistem yang berbeda, berbiaya murah, efesien dan efektif. Salah satu terobosannya dengan menggunakan model arbitrase online, yang dikenal dengan istilah Online Dispute Resolution (ODR), sehingga pihakpihak yang bersengketa dapat menyelesaikan dimana saja dia berada. Pada umumnya, para pihak lebih menyukai penyelesaian sengketa ODR melalui arbitrase online karena sifat keputusannya yang final dan binding. Meskipun, di dalam ODR terdapat suatu fenomena baru dimana putusan arbitrase online yang bersifat non binding. Adapun metode komunikasi online yang dapat digunakan, antara lain : e-mail, instant messaging, chat, threaded discussion, video/audio stream, teleconfrence, dan video conference ${ }^{3}$.

Pengaplikasian arbitras online memang banyak menawarkan efektifitas dan efesiensi yang besar dibandingkan dengan arbitrase

\footnotetext{
2 Moch. Basarah, 2011, Prosedur Penyelesaian Sengketa Arbitrase Tradisional Dan Modern (Online), Genta Publishing, Yogyakarta, hlm.2. 3 Ibid
}

konvensional, khususnya biaya yang terkadang justru lebih mahal dari proses litigasi dapat diminimalisasi. ${ }^{4}$ Dalam keadaan tertentu, Online Disbute Resolution (ODR) diharapkan merupakan satu-satunya cara penyelesaian sengketa untuk memperoleh keadilan, karena cara penyelesaian sengketa yang lain memerlukan biaya yang tidak sedikit.

Dengan adanya keharusan bertemu muka, antara para pihak dengan hakim, arbiter, atau dengan mediator akan memerlukan biaya perjalanan, penginapan, biaya administrasi serta konsultasi. Tetapi dalam ODR biaya tersebut tidak diperlukan, dengan perkataan lain, terdapat perbedaan keuntungan penyelesaian sengketa melalui ODR ini yaitu biaya yang dikeluarkan sangat sedikit ${ }^{5}$.

ODR sebetulnya bukan merupakan konsep yang sangat baru, karena tata cara antara Alternatif Penyelesaian Sengketa (APS) dengan Alternatif Penyelesaian Sengketa secara online (ODR) tidak jauh berbeda. Perbedaan yang sangat mendasar antara APS dengan ODR adalah jika dalam ODR penyelesaian sengketa antara para pihak dapat dilakukan tanpa kehadirannya secara fisik. Pada kenyataannya saat ini dalam beberapa peristiwa penyelesaian sengketa melalui ODR terus meningkat. Karena ODR akan lebih mematuhi standar minimum tertentu dalam memelihara mutu dan ketidakberpihakannya (fairness).

Dengan perkembangan teknologi yang semakin canggih, hal ini turut berimbas kepada arbitrase, yang dapat juga dilaksanakan secara online melalui internet, hal ini tentu akan sangat membantu para pihak, dari segi waktu dan biaya. Apakah itu arbitrase online, bagaimana mekanisme, dan dasar hukum bagi pemilihan arbitrase online adalah objek, dan apakah dasar bagi pemberlakuan putusan arbitrase online, adalah beberapa masalah yang ingin ditelaah oleh penulis dalam tulisan ini ${ }^{6}$. Berdasarkan pada uraian yang telah dikemukakan di atas, penulis merumuskan permasalah sebagai berikut:

4 Bambang Sutioso, 2008, Hukum Arbitrase dan Alternatif Penyelesaian Sengketa, Gama Media, Yogyakarta, hlm.184.

5 Moch. Basarah, op. cit., hlm.101

6 Ibid. 
1. Bagaimana proses penyelesaian sengketa secara Online Dispute Resolution(ODR)?

2. Bagaimana konsep Online Dispute Resolution (ODR) di Indonesia ditinjau dari Undang-undang Nomor 30 Tahun 1999?

\section{B. METODE PENELITIAN}

Penelitian ini menggunakan metode Yuridis Normatif, yang merupakan pendekatan terhadap hukum positif atau peraturan perundangundangan, maksudnya adalah merupakan pendekatan dengan memaparkan, menganalisis dan mengevaluasi peraturan perundang-undangan yang berkaitan dengan masalah Online Dispute Resolution (ODR). Spesifikasi penelitian ini adalah termasuk penelitian diskriptif analitis, yaitu menggambarkan segala sesuatu yang berkaitan dengan Online Dispute Resolution (ODR) kemudian dianalisis untuk mendapatkan upaya hukum yang lebih efektif dalam penerapan konsep Online Dispute Resolution (ODR) di Indonesia. Metode yang digunakan untuk menganalisa data adalah kualitatif normatif, yaitu dari bahan hukum yang telah dikumpulkan sesuai dengan permasalahan yang diteliti kemudian dianalisis secara kualitatif sehingga dapat menghasilkan suatu kesimpulan yang digunakan untuk menjawab masalah yang dibahas.

\section{HASIL PENELITIAN DAN PEMBAHASAN}

1. Proses Penyelesaian Sengketa Secara Online Diputes Resolution

Pada bulan Maret 1998 dalam "communication on the out of court settlement of court consumer disputes", komisi Eropa telah mempresentasikan standar minimun dari proses ODR, antara lain: ${ }^{7}$

1. Pembuat keputusan harus bersifat independen dari segala asosiasi profesional yang menunjuk dirinya (independen).

2. Proses dalam penyelesaian sengketa harus bersifat transparan (prinsip transparan).

3. Para pihak harus diberikan kesempatan yang sama untuk mengemukakan

\footnotetext{
7 Ibid.
}

pendapatnya, serta diberikan akses yang sama untuk membuktikan (prinsip adversarial).

4. Konsumen harus mampu untuk mewakili dirinya sendiri dalam proses penyelesaian sengketa dan bebas dari biaya apapun. Putusan harus dibuat secara cepat dan pembuat putusan harus mempunyai peran aktif dalam proses penyelesaian sengketa (prinsip efektifitas).

5. Konsumen tidak boleh dikesampingkan dari ketentuan/aturan wajib dari hukum tempat badan pembuat keputusan berada dan dari negara dimana konsumen tercacat sebagai warga negara (prinsip legalitas).

6. Jika putusan mengikat kepada konsumen tanpa bantuan pengadilan, maka konsumen harus menerimanya dan bersikap waspada (prinsip kebebasan).

7. Pada semua tahap penyelesaian sengketa, konsumen dapat diwakili oleh atau dibantu oleh pihak ketiga, misalnya pengacara (prinsip perwakilian).

Adapun prosedur dasar dalam proses penyelesaian sengketa melalui arbitrase online, meliputi: ${ }^{8}$

1. Perjanjian untuk menyelesaikan sengketa melalui arbitrase online.

a) Para pihak harus mempertimbangkan mengenai prosedur dari provider tertentu yang akan digunakan dalam penyelesaian sengketa sebagai bagian dari perjanjian arbitrase, misalnya melalui AAA (American Arbitration Association). Oleh karenanya, dalam pemeriksaan permulaan akan dilakukan berdasarkan prosedur yang telah dipilih oleh para pihak.

b) Provider yang telah dipilih tidak dapat menjalankan tugas sebagaimana mestinya apabila

8 http://www.arbitrationlaw.com/online diakses pada 3 September 2013. 
para pihak tidak mempunyai kapasitas untuk menyelesaikan sengketa melalui arbitrase dan/ atau sengketa yang terjadi tidak berkaitan dengan bidang perdagangan atau bidang-bidang lainnya yang telah ditentukan.

c) Dengan menyetujui prosedur dari provider tertentu, maka para pihak juga menyetujui perubahan portal terms ${ }^{9}$ ketika dilakukan pemeriksaan permulaan.

d) Ketika para pihak menyatakan setuju untuk menyelesaikan sengketanya melalui arbitrase secara online, maka pada saat itu provider yang telah dipilih mempunyai kewenangan untuk menyelesaikan sengketa tersebut.

2. Pemberitahuan kepada para pihak dan perhitungan jangka waktu penyelesaian sengketa.

a) Apabila tidak ditentukan lain, berdasarkan kesepakatan para pihak dan persetujuan dari arbiter maka setiap dokumen yang dibuat berdasarkan prosedur dari provider yang telah dipilih harus sudah dikirim kepada case site pada waktu dan hari yang telah ditentukan. Waktu dan hari penerimaan dokumen melalui e-mail akan ditetapkan sebagai waktu dibuatnya dokumen tersebut oleh para pihak.

b) Jangka waktu penyelesaian sengketa akan dihitung sejak diterimanya dokumen tersebut di case site.

9 Portal Terms adalah "terdiri dari administrative site dan case site yang dari waktu ke waktu dapat diubah oleh provider tertentu. Administrative site adalah situs internet www.adr.org, diamana situs tersebut memberikan fasilitas untuk pembayaran administratif dan biaya lainnya, jadwal pembayaran, petunjuk secara teknis dalam menyusun format sebuah dokumen, serta informasi yang penting lainnya. Sedangkan case site adalah situs internet yang berkaitan dengan file dan dokumen yang dibuat oleh para pihak dan arbiternya, yang mana hanya para pihak dan arbiternya yang dapat mengakses situs tersebut.," diakses pada tanggal 3 September 2013.
3. Tuntutan yang diajukan dalam arbitrase online.

a) Pemohon harus membuat dokumen yang berisi tuntutan kepada administrative site. Tuntutan dalam arbitrase harus mencakup: perjanjian arbitrase, perjanjian diantara para pihak berkaitan dengan jumlah, identitas, kualifikasi, dan cara penunjukkan arbiter, pernyataan mengenai sengketa yang terjadi, alasan hukum yang melatarbelakangi tuntutan, jumlah ganti kerugian yang diinginkan (jika ada).

b) Tuntutan yang diajukan oleh pemohon juga harus memuat informasi berikut:

1) Alamat e-mail dari pemohon;

2) Alamat e-mail dari termohon;

3) Nama, alamat, nomor telepon dan faximili dari para pihak.

c) Pemohon harus membayar sejumlah biaya 5 hari sebelum diajukan tuntutan ke admistrative site. Biaya tersebut dapat dibayar secara elektronik atau metode lainnya yang telah ditentukan oleh provider.

4. Pemberitahuan isi tuntutan.

a) Setelah pembayaran dilakukan, kemudian provider tersebut akan memeriksa tuntutan yang diajukan oleh pemohon apakah sudah sesuai dengan point 3 diatas. Apabila sudah sesuai, maka dalam jangka waktu 5 (lima) hari kerja, provider akan memberitahukan kepada para pihak alamat internet dari case site yang telah dibuat untuk digunakan oleh para pihak. Waktu dan tanggal diberitahukannya alamat case site kepada para pihak melalui e-mail ditetapkan sebagai waktu dan tanggal dibuatnya case site tersebut.

b) Jika termohon tidak dapat diberitahukan melalui e-mail, maka provider akan menetapkan bahwa prosedur yang telah dipilih tidak dapat digunakan, 
c) Jika provider menetapkan bahwa tuntutan yang tidak memenuhi syarat secara formal, maka provider tersebut tidak akan membuat case site dan pemohon harus melengkapinya terlebih dahulu.

5. Jawaban atas tuntutan.

Dalam jangka waktu 30 (tiga puluh) hari terhitung sejak dibuatnya case site, pihak termohon harus menjawab tuntutan, yang mencakup:

a) Jawaban dari tuntutan yang diajukan oleh para pihak pemohon, yang meliputi: fakta-fakta, dokumen, dan alasan hukum.

b) Keberatan kepada arbiter, berkaitan dengan jumlah, identitas, kualifikasi, dan/atau cara penunjukkan arbiter.

c) Alamat e-mail dari termohon.

d) Jika termohon akan mengajukan tuntutan balasan, maka dokumen yang diajukan disesuaikan dengan persyaratan yang dinyatakan dalam poin 3.

6. Jawaban atas tuntutan balasan. Apabila termohon mengajukan tuntutan balasan, maka pihak pemohon harus menjawab tuntutan balasan tersebut dalam jangka waktu 30 (tiga puluh) hari sejak diterimanya tuntutan balasan di case site. Jawaban dari pemohon tersebut harus mencakup informasi yang ditentuan dalam poin 5.

7. Perpanjangan jangka waktu penyelesaian sengketa.

Provider atau arbiter, dengan suatu alasan yang logis, dapat memperpanjang jangka waktu, seperti jangka waktu dari termohon untuk menjawab tuntutan dari pemohon atau dari pemohon untuk menjawab tuntutan balasan dari termohon.

8. Bahasa yang digunakan.

Bahasa yang digunakan dalam penyelesaian sengketa adalah bahasa yang digunakan dalam perjanjian arbitrase, kecuali ditentukan lain oleh para pihak atau berdasarkan kewenangan dari arbiter.
9. Proses hearing. ${ }^{10}$

a) Apabila para pihak dengan persetujuan dari arbiter setuju untuk melaksanakan proses hearing, maka arbiter akan membuat putusan arbitrase berdasarkan kepatuhan para pihak. Apabila tidak dilakukan proses haering, maka arbiter akan membuat putusan dalam jangka waktu 30 (tiga puluh) hari terhitung sejak proses ditutup.

b) Dalam proses haering, kesaksian dapat diterima, pemeriksaan silang dari para saksi dapat dilakukan, dan dokumen tambahan dapat diterima sebagai alat bukti oleh arbiter.

10. Tempat dari putusan.

Tempat dari putusan dapat ditentukan oleh para pihak, apabila para pihak tidak menentukan, maka tempat dari putusan ditentukan oleh arbiter.

11. Memberitahukan isi putusan.

Arbiter harus menyediakan putusan di dalam case site. Waktu dan tanggal dikirimnya putusan kepada para pihak dari case site, ditetapkannnya sebagai waktu dan tanggal putusan dibuat. Case site akan tetap tersedia selama 30 (tiga puluh) hari sejak dibuatnya putusannya.

12. Metode komunikasi yang digunakan.

a) Arbiter dapat menentukan metode komunikasi yang akan digunakan di luar dari metode komnukasi yang digunakan dalam case site.

b) Provider harus menyediakan alamat e-mail untuk para pihak dan arbiter, yang mana para pihak dan provider atau arbiter dengan provider dapat tepat berhubungan.

Penetapan peraturan tentang tata cara proses online haruslah sesuai dengan kebutuhan dari aturan hukum wajib yang dapat dipakai pada tempat atau kedudukan arbitrase walaupun tempat atau kedudukan arbitrase

10 Haering adalah suatu proses pertemuan diantara para pihak bersama dengaan arbiter, atau di antara para pihak dengan menggunakan telepon, videoconferencing, dll. 
tersebut mungkin bersifat tidak nyata. Selain itu, tata cara proses online tidak boleh bertentangan dengan kepentingan umun (public policy).

2. Konsep Online Dispute Resolution (ODR) di Indonesia Ditinjau dari Undang-Undang Nomor 30 Tahun 1999

Pasal 1 ayat (3) UU No. 30 Tahun 1999, menyatakan bahwa perjanjian arbitrase harus dibuat secara tertulis, seperti dinyatakan sebagai berikut:

"Perjanjian arbitrase adalah suatu kesepakatan berupa klausula arbitrase yang tercantum dalam suatu perjanjian tertulis yang dibuat para pihak sebelum timbul sengketa, atau suatu perjanjian arbitrase tersendiri yang dibuat para pihak setelah timbul sengketa."

Kemudian diperkuat lagi oleh Pasal 9 UU No. 30 Tahun 1999 yang menyatakan bahwa:

(1) Dalam hal para pihak memilih penyelesaian sengketa melalui arbitrase setelah sengketa terjadi, persetujuan mengenai hal tersebut harus dibuat dalam suatu perjanjian tertulis yang ditandatangani oleh para pihak.

(2) Dalam hal para pihak tidak dapat menandatangani perjanjian tertulis sebagaimana dimaksud dalam ayat (1), perjanjian tertulis tersebut harus dibuat dalam bentuk akta notaris.

(3) Perjanjian tertulis sebagaimana dimaksud dalam ayat (1) harus memuat :

1. masalah yang dipersengketakan;

2. nama lengkap dan tempat tinggal para pihak;

3. nama lengkap dan tempat tinggal arbiter atau majelis arbitrase;

4. tempatarbiteratau majelis arbitrase akan mengambil keputusan;

5. nama lengkap sekretaris;

6. jangka waktu penyelesaian sengketa;
7. pernyataan kesediaan dari arbiter; dan

8. pernyataan kesediaan dari pihak yang bersengketa untuk menanggung segala biaya yang diperlukan untuk penyelesaian sengketa melalui arbitrase.

(4) Perjanjian tertulis yang tidak memuat hal sebagaimana dimaksud dalam ayat (3) batal demi hukum.

Oleh karena itu, UU No. 30 Tahun 1999 mensyaratkan perjanjian arbitrase dalam bentuk tertulis, karena tidak terdapat ketentuan mengenai arbitrase yang dibuat secara elektronik. Hal ini juga dinyatakan dalam ketentuan Konvensi New York Pasal II ayat (2), yaitu:

"The trem "agreement in writing shall included an arbitral clause in a contract or an arbitration agreement, signed by the parties or contained in an exanged of letters or telegrams" Sedangkan dalam Pasal 54 UU No. 30 Tahun 1999, menyatakan bahwa putusan arbitrase internasional harus dibuat secara tertulis dan ditandatangani oleh para pihak serta arbiter yang menangani sengketa tersebut.

Undang-undang No. 30 Tahun 1999 membedakan antara putusan arbitrase nasional dan putusan arbitrase asing. Dalam pelaksanaan putusan arbitrase nasional berlaku ketentuan yang dinyatakan dalam Pasal 59 , yang menyatakan sebagai berikut:

(1) Dalam waktu paling lama 30 (tiga puluh) hari terhitung sejak tanggal putusan diucapkan, lembar asli atau salinan otentik putusan arbitrase diserahkan dan didaftarkan oleh arbiter atau kuasanya kepada Panitera Pengadilan Negeri.

(2) Penyerahan dan pendaftaran sebagaimana dimaksud dalam ayat (1), dilakukan dengan pencatatan dan penandatanganan pada bagian akhir atau di pinggir putusan oleh Panitera Pengadilan Negeri dan arbiter atau kuasanya yang menyerahkan, dan 
catatan tersebut merupakan akta pendaftaran.

(3) Arbiter atau kuasanya wajib menyerahkan putusan dan lembar asli pengangkatan sebagai arbiter atau salinan otentiknya kepada Panitera Pengadilan Negeri.

(4) Tidak dipenuhinya ketentuan sebagaimana dimaksud dalam ayat (1), berakibat putusan arbitrase tidak dapat dilaksanakan.

(5) Semua biaya yang berhubungan dengan pembuatan akta pendaftaran dibebankan kepada para pihak.

Namun, untuk pelaksanaan putusan arbitrase asing, harus memenuhi persyaratan yang dinyatakan dalam Pasal 66 UU No. 30 Tahun 1999, sebagai berikut:

Putusan Arbitrase Internasional hanya diakui serta dapat dilaksanakan di wilayah hukum Republik Indonesia, apabila memenuhi syarat-syarat sebagai berikut :

a. Putusan Arbitrase Internasional dijatuhkan oleh arbiter atau majelis arbitrase di suatu negara yang dengan negara Indonesia terikat pada perjanjian, baik secara bilateral maupun multilateral, mengenai pengakuan dan pelaksanaan Putusan Arbitrase Internasional;

b. Putusan Arbitrase Internasional sebagaimana dimaksud dalam huruf a terbatas pada putusan yang menurut ketentuan hukum Indonesia termasuk dalam ruang lingkup hukum perdagangan;

c. Putusan Arbitrase Internasional sebagaimana dimaksud dalam huruf a hanya dapat dilaksanakan di Indonesia terbatas pada putusan yang tidak bertentangan dengan ketertiban umum;

d. Putusan Arbitrase Internasional dapat dilaksanakan di Indonesia setelah memperoleh eksekuatur dari Ketua Pengadilan Negeri Jakarta Pusat; dan

e. Putusan Arbitrase Internasional sebagaimana dimaksud dalam huruf a yang menyangkut Negara Republik Indonesia sebagai salah satu pihak dalam sengketa, hanya dapat dilaksanakan setelah memperoleh eksekuatur dari Mahkamah Agung Republik Indonesia yang selanjutnya dilimpahkan kepada Pengadilan Negeri Jakarta Pusat.

Dalam pelaksanaan putusan arbitrase internasional berlaku ketentuan dalam Pasal 67, yaitu:

(1) Permohonan pelaksanaan Putusan Arbitrase Internasional dilakukan setelah putusan tersebut diserahkan dan didaftarkan oleh arbiter atau kuasanya kepada Panitera Pengadilan Negeri Jakarta Pusat.

(2) Penyampaian berkas permohonan pelaksanaan sebagaimana dimaksud dalamayat(1)harus disertai dengan:

a. lembar asli atau salinan otentik Putusan Arbitrase Internasional, sesuai ketentuan perihal otentifikasi dokumen asing, dan naskah terjemahan resminya dalam Bahasa Indonesia;

b. lembar asli atau salinan otentik perjanjian yang menjadi dasar Putusan Arbitrase Internasional sesuai ketentuan perihal otentifikasi dokumen asing, dan naskah terjemahan resminya dalam bahasa Indonesia; dan

c. keterangan dari perwakilan diplomatik Republik Indonesia di negara tempat Putusan Arbitrase Internasional tersebut ditetapkan, yang menyatakan bahwa negara pemohon terikat pada perjanjian, baik secara bilateral maupun multilateral dengan negara Republik Indonesia perihal pengakuan dan pelaksanaan Putusan Arbitrase Internasional.

Berkaitan dengan penetapan klausul arbitrase dalam perjanjian pokok secara online, dalam UU No. 30 Tahun 1999, dikenal 2 (dua) macam klausula arbitrase, yaitu: pactum de compremitendo 
dan akta kompromis. Bentuk klausul pactum de compremitendo ditetapkan sebelum sengketa terjadi, yang mana pembuatannya dapat bersamaan dengan saat pembuatan perjanjian pokok atau sesudahnya. Ini berarti perjanjian arbitrase tersebut menjadi bagian dari perjanjian.

Sedangkan akta kompromis adalah perjanjian khusus yang ditetapkan setelah terjadinya sengketa guna mengatur tentang cara mengajukan sengketa yang telah terjadi kepada seorang atau beberapa orang arbiter untuk diselesaikan, berarti akta kompromis dibuat sebagai perjanjian yang tersendiri di luar perjanjian pokok.

Dalam Pasal 37 ayat (1) UU No. 30 Tahun 1999 menentukan bahwa tempat kedudukan arbitrase oleh para pihak, namun apabila para pihak tidak menentukan tempat kedudukan arbitrase, maka tempat kedudukan ditentukan oleh arbiter.

Selain itu berdasarkan Pasal 34 ayat (2) menyatakan peraturan dan acara yang akan digunakan dalam proses penyelesaian sengketa juga ditentukan oleh para pihak, tetapi apabila para pihak tidak menentukannya, maka peraturan dan acara yang akan digunakan dilakukan menurut peraturan dan acara dari lembaga yang dipilih.

Dalam UU No. 30 Tahun 1999, celah untuk melakukan arbitrase online dapat dilihat dari ketentuan Pasal 4 ayat (3) sebagai berikut:

"Dalam hal disepakati penyelesaian sengketa melalui arbitrase terjadi dalam bentuk pertukaran surat, maka pengiriman teleks, telegram, faksimili, e-mail atau dalam bentuk sarana komunikasi lainnya, wajib disertai dengan suatu catatan penerimaan oleh para pihak. "

Dari ketentuan tersebut diatas, maka menurut penulis pemilihan arbitrase secara online dapat terjadi asalkan terdapat kesepakatan antara para pihak. Redaksi pasal di atas terdapat kata "e-mail" yang memungkinkan para pihak dapat menggunakan internet sebagai sarana penyelesaian sengketa baik melalui arbitrase konvensional maupun secara lainnya. Karena e-mail atau surat elektronik pengiriman dan penerimaannya hanya dapat dilakukan melalui sarana internet.

Dapat diakuinya atau tidak ODR ini dalam hukum di Indonesia yang termaktub dalam UU No. 30 Tahun 1999 dan pelaksanaannya di Indonesia, bisa dicermati dari pengaturan hukum konvensional yang menyatakan bahwa setiap pelaksanaan putusan arbitrase domestik maupun asing senantiasa mensyaratkan adanya pendaftaran di Pengadilan Negeri, dan untuk putusan arbitrase asing pendaftaran dilakukan di Pengadilan Negeri Jakarta Pusat. Dari konteks ini yang menjadi pertanyaan adalah apakah ODR ini dapat juga didaftarkan di Pengadilan Negeri. Dalam hukum Indonesia, dalam hal ini UU No. 30 Tahun 1999 belum memberikan pengaturan secara tegas. Sehingga jika dilihat dari sisi yuridisnya wajar apabila ODR merupakan sesuatu yang patut dipertanyatakan dalam sistem hukum acara perdata di Indonesia yang mengatur tentang masalah penyelesaian sengketa. Walaupun dalam kenyataanya, di Indonesia belum ada situs yang mencoba mengembangkan sistem penyelesaian sengketa secara ODR ini, namun harus diingat bahwa keberadaan situs negara lain yang memberikan layanan ODR (seperti www.adronline.com) ini juga pada akhirnya dan sekarangpun sudah masuk ke wilayah hukum Indonesia. ${ }^{11} \mathrm{Hal}$ ini memungkinkan para users di Indonesia memanfaatkan jasa layanan internet ini untuk menyelesaikan sengketasengketa mereka.

Dariuraian diatas, penulis berpendapat bahwa Online Dispute Resolution (ODR), memang belum diatur secara rinci dan

11 Bambang Sutiyoso, Op.Cit.hlm. 222 
secara tegas dalam UU No. 30 Tahun 1999, namun kewenangan Pengadilan Negeri Jakarta Pusat untuk menerima ODR sebagai bentuk putusan arbitrase internasional (berdasarkan Pasal 66). Lebih lanjut, jika kembali kepada asas kebebasan berkontrak, pada prinsipnya arbitrase terjadi berdasarkan kesepakatan para pihak. Misalnya, para pihak sepakat bahwa penyelesaian sengketa yang akan ditempuh melalui arbitrase online. Namun karena Undang-undang menentukan putusan arbitrase harus asli dan otentifikasi terjamin, maka untuk memenuhi ketentuan Undang-undang tersebut harus ada kesepakatan yaitu putusan dapat dikirim aslinya melalui pos atau sejenisnya. Dengan demikian, putusan arbitrase yang diperoleh para pihak akan asli, karena putusan tersebut secara fisik diterima langsung oleh para pihak.

Lebih lanjut masalah arbitrase online tidak dapat lepas dari sudut pandang tekhnologi informasi. Maka dari itu, sejak disahkannya UU No. 11 Tahun 2008 Tentang Informasi dan Transaksi Elektronik maka Indonesia telah memasuki era baru dalam penggunaan tekhnologi dan informasi. UU No. 11 Tahun 2008 sangat diperlukan bagi Indonesia, karena Indonesia merupakan salah satu negara yang telah menggunakan dan memanfaatkan tekhnologi informasi secara luas. Pelanggaran hukum dalam transaksi elektronik dan perbuatan hukum di dunia maya merupakan fenomena yang banyak terjadi saat ini, yang memanfaatkan informasi untuk menjadi bagian dari aktivitas pelaku kejahatan internet. Teknologi informasi dan komunikasi ini dapat memberikan manfaat yang positif, namun di sisi yang lain, juga perlu disadari bahwa teknologi ini memberikan peluang pula untuk dijadikan media melakukan tindak pidana atau kejahatan-kejahatan yang disebut secara popular sebagai cyber crime (kejahatan di dunia maya) sehingga diperlukan hukum dunia maya (Cyber Law). ${ }^{12}$

\section{PENUTUP}

\section{Kesimpulan}

a. Proses penyelesaian sengketa secara online terdiri dari:

a) Para pihak setuju dalam bentuk perjanjian untuk menyelesaikan sengketa melalui arbitrase online.;

b) Pemberitahuan kepada para pihak dan perhitungan jangka waktu penyelesaian sengketa oleh Provider.;

c) Pemohon harus membuat dokumen yang berisi tuntutan kepada administrative site;

d) Pemberitahuan isi tuntutan Pemohon kepada Termohon oleh Provider;

e) Jawaban atas tuntutan Pemohon oleh Termohon.;

f) Jawaban atas tuntutan balasan.

g) Perpanjangan jangka waktu penyelesaian sengketa;

h) Menggunakan bahasa yang digunakan dalam perjanjian arbitrase,

i) Melakukan hearing;

j) Tempat dari putusan dapat ditentukan oleh para pihak, apabila para pihak tidak menentukan, maka tempat dari putusan ditentukan oleh arbiter

k) Memberitahukan isi putusan.

b. Konsep Online Dispute Resolution (ODR), memang belum diatur secara rinci dan secara tegas dalam UU No. 30 Tahun 1999, namun kewenangan berada pada Pengadilan Negeri Jakarta Pusat untuk menerima ODR sebagai bentuk putusan arbitrase internasional (berdasarkan Pasal 66).

12 http://mustaghfirin.blog.unissula.ac.id/2011/10/18/ fenomena-kejahatan-dunia-maya-cyber-criemdan-aplikasi-hukumannya-menuju-ketertiban-dankedamean-masyarakat/ diakses pada tanggal 9 september 2013. 


\section{Saran}

a. Mengingat era globalisasi yang saat ini, yang telah merambah Indonesia dan juga semakin banyaknya warga negara Indonesia yang melakukan transaksi secara online di luar negeri. Tidak menutup kemungkinan kedepannya banyak warga Indonesia yang akan menggunakan sistem ODR ini dalam menyelesaikan sengketa bisnis mereka. Oleh karena itu, baiknya bagi para users dapat membuat provider ODR yang berbasis di Indonesia. b. Bagi pemerintah, sebaiknya membuat regulasi secara khusus dan tegas yang mengatur tentang ODR ini, karena untuk mengantisipasi adanya putusan yang dibawa ke wilayah hukum Indonesia untuk diminta eksekusinya. Aturan tersebut terdapat Undang-undang, atau dengan kata lain merevisi UndangUndang Nomor 30 Tahun 1999 Tentang Arbitrase dan Alternatif Penyelesaian sengketa dengan memasukkan pasal yang mengatur secara tegas mengenai Online Dispute Resolution (ODR) di Indonesia.

\section{DAFTAR PUSTAKA}

\section{- Buku-Buku}

Bambang Sutiyoso, 2008, Hukum Arbitrase dan Alternatif Penyelesaian Sengketa, Gama Media, Yogyakarta.

M. Ali Mansyur, 2012, Peran Hukum Dalam Menjawab Perkembangan Ekonomi, Badan Penerbit Universitas Diponegoro, Semarang.

Moch. Basarah, 2011, Prosedur Penyelesaian Sengketa Arbitrase Tradisional Dan Modern (Online), Genta Publishing, Yogyakarta.

Munir Fuady, 2003, Arbitrase Nasional; Alternatif Penyelesaian

\section{- Peraturan Perundang-Undangan}

Undang-Undang Dasar Negara Republik Indonesia tahun 1945

Undang-Undang Nomor 30 Tahun 1999 Tentang Arbitrase dan Alternatif Penyelesaian Sengketa.

Undang-Undang Nomor 11 Tahun 2008 Tentang Informasi Transaksi Elektronik.

Undang-Undang Nomor 48 Tahun 2009 Tentang Kekuasaan Kehakiman.

\section{- Internet}

http://www.arbitrationlaw.com/online,

http://www.odrnews.com

http://vanezintania.wordpress.com/2011/05/22/alternatif-penyelesaian-sengketa-umum-apsu/ http://mustaghfirin.blog.unissula.ac.id/2011/10/18/fenomena-kejahatan-dunia-maya-cybercriem-dan-aplikasi-hukumannya-menuju-ketertiban-dan-kedamean-masyarakat/ http://kuliahhukumonline.blogspot.com/2012/05/alternatif-penyelsaian-sengketa-adr.html 